\title{
Sustainability and Corporate Social Responsibility in Green Supply Chain Management
}

\author{
Abdurehman Munir ${ }^{1}$, Hong Wang ${ }^{2}$ \\ \{abdurehman007@gmail.com¹,13901601536@163.com² \\ Shanghai University, People's Republic of China ${ }^{1}$, Shanghai University, People's Republic of China ${ }^{2}$
}

\begin{abstract}
This research work, as a review about concepts of sustainability, CSR and green supply chain management (GSCM), discusses latest literature and explains the role of sustainability and CSR in GSCM for businesses and sees how they are contributing in development of environment and social responsibilities through green practices in developing countries specifically in Pakistan. We take a manufacturing company named as Lucky Cement, as its case study from Pakistan that has adopted the sustainability and CSR practices in its one of the core business objectives and bring more innovations along with green supply chain management. We find that Lucky Cement follows both sustainability and CSR in their green supply chains. The stated company follows the Triple Bottom Line/3Ps but not aligned to 5Ps mentioned in UN agenda. This company needs to focus on problems by following guidelines prescribed by UN. This study is a contribution in terms of reviewing the available literature and binding them with a specific case study (Lucky Cement) to observe the argument created by this work.
\end{abstract}

Keywords: Sustainability, Corporate Social Responsibility, Green Supply Chain Management, Pakistan 


\section{Introduction}

In last few years, the area of sustainability and CSR in green supply chain management has turned out to be very important. Sustainability has become an emerging practice for the businesses which is bringing a very vital change into the competition and becoming a quick driver of innovation in businesses. Firms in all areas of the supply chains have started to follow a different kind of green initiatives for getting distinctive position and advantage in the competitive industry [30]. By taking into consideration the reality of supply chain management which mediate the product from starting process of raw material till delivery to the end user. The main point for supply chain management is that adoption of this concept should be at large scale which can help in development of sustainability. Sustainability concept in supply chain management has been explained by means of many terms in the theoretical work. The three terms used that have very close link with supply chain management and sustainability theories are supply chain management (SCM), green supply chain management (GSCM) and sustainability supply chain management (SSCM) [3].

Asian organizations are also increasingly implementing the corporate social responsibility (CSR) by following global momentum, because CSR has the ability to get high increase in sales revenues and market share by cultivating customers' perception of an organization. Corporate social responsibility has grabbed more attention from supply chain professional, because the conduct of supply chain management (SCM) can have a big and important effect on the reputation of a firm [4].

Several studies of sustainability and CSR relating to supply chain management have published in the journals related to supply chain management as well as in journals of business ethics. Business ethics area is very interesting because it all related the researched about sustainability and CSR beyond the main firm. It is always interesting and worth to do research how sustainability and corporate social responsibility in supply chains are connected with each other in all fields [1], [8], [34]. In last few decades, Corporate Social Responsibility reporting has gained high amount of interest in academic institutions, firms, industries and policy makers. Companies find the way for communicating their CSR progress. Sustainability reports mainly prepared from the initiatives and activities taken by any company which have environmental and social impacts on the society but there is no such standard how to make sustainability report. There is a standard by GRI (Global Reporting Initiative) for sustainability reports which support companies to get 
to know about requirements, understand, measure, evaluate their sustainability performance and publish final results in the same way ${ }^{1}$. The first task for the fast development of SCM is economic sustainability and efficient SCM always support in increasing revenues and decreasing risk at monetary level [3].

The purpose of writing this paper is to provide a latest review of researches, popularity and impacts after the practical use of CSR and sustainability by linking it with green supply chain management. The latest review results and observations are suggested to use as foundation in studies on how companies follow sustainability and CSR in their core operations of green supply chain management and how they take initiatives to protect the environment and take an active part in social responsibilities.

\section{Literature Review}

Sustainability, CSR and green supply chain management are three different independent concepts which have been very popular in debates in last few years. There is a growing combination in between sustainability and CSR in green supply chain management which shows more areas are also getting interactions within these concepts. By taking this trend into consideration and do more research to check the integration of these concepts with each-other, an overview for each of these topics is in few sections written below. This will help in providing a foundation for establishing a relation and importance of Sustainability, CSR from the GSCM perspective.

\subsection{Sustainability}

Sustainability problems are getting more attention in all major businesses. Initiative taken for business sustainability are often named under the title of "Corporate Sustainability" and being consider as more important and prominent part for a business. Initiatives taken for sustainability are more related with initiatives taken for CSR.

In the case of business, standard argument is not that strategies for sustainability are good choice for every company in every situation, there should be something specific applied for the operations of an individual company according to the circumstances within an industry. Success of some companies in an industry can be good example, but there is still need that case

\footnotetext{
${ }^{1}$ Source: GRI report reference for SCR sustainability report: https://www.globalreporting.org/resourcelibrary/GRIG4-Part1-Reporting-Principles-and-StandardDisclosures.pdf
} 
to be applied on one company at one time [27]. Although sustainability and CSR are two different concepts because social issues are mostly being discussed in CSR and environmental issues are likely to be discussed in environmental management [11]. In past few years, sustainability and CSR together have involved in many aspects and moving toward an ordinary prospect. These two concepts share the same views to bring balance in economic, social and environmental issues [24].

The idea of sustainability was launched as an environmental initiative and the focus was only into preservation of resources. Now, it has considered as a big milestone for the whole business community. The most famous definition of sustainability that has become the triple bottom line known as TBL with consideration of economic feasibility, social responsibilities as well as environmental duties [32].

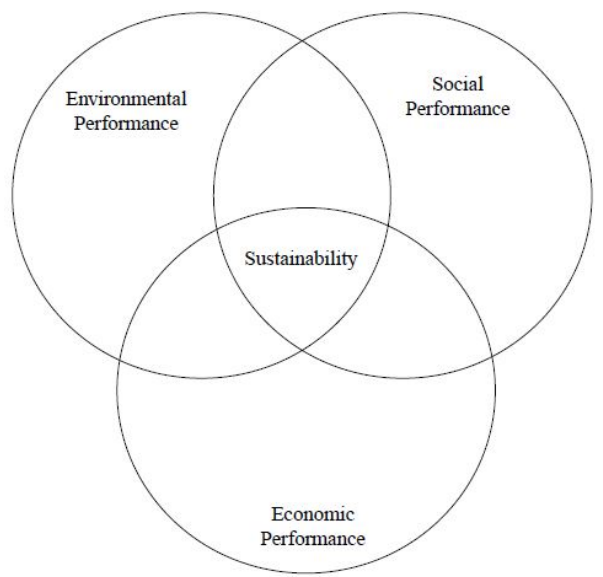

Fig. 1. Sustainability: The Triple Bottom Line (TBL) ${ }^{2}$

The triple bottom line, known as TBL, proposes that right at the intersection of all three levels mention in the Figure 1. in sense of their performance. As author stated about some initiatives which companies could participate in not for only positive affect to society and the natural environment but also bring into consideration competitive advantage and long term economic benefits for the organizations [14]. Concentration of a single minded person on an economic condition can be beneficial in short term, on the other hand it requires, for long term, all three aspects should be satisfied at

\footnotetext{
${ }^{2}$ Source: Craig R. Carter, Dale S. Rogers, (2008) "A framework of sustainable supply chain management: moving toward new theory", International Journal of Physical Distribution \& Logistics Management, Vol. 38 Issue: 5, pp.360-387.
} 
the same time. Furthermore, when sustainability idea transfers to corporate level, it should meet the requirements of all stakeholders of a firm and should not compromise with the positive capabilities of a company to satisfy them [15].

As the research about literature done by Montiel [25] helped to highlight an ambiguity about sustainability whether it should be a bidimensional construct (environmental and social) or a tri-dimensional concept (social, economic and environmental). However, many researchers agree by looking on this definition that includes social, economic and environmental areas even they are with different terms like the 3Ps (people, planet and profit) or TBL were in use [5]. SRB model is built by TBL or the triple bottom line with an approach to incorporate the economic, social and environmental progress in the activities of a firm. The triple bottom line or TBL normally pays attention on the balance of these three terms that the basic line of making profits for the firm and its shareholders, social bottom line to make sure that activities of the firm have not any adverse impact on the community and lastly, environment bottom line means the initiatives took by company are creating environmental issues. TBL term is often called as 3Ps because it includes: profits, people and planet see Figure 2. [20].

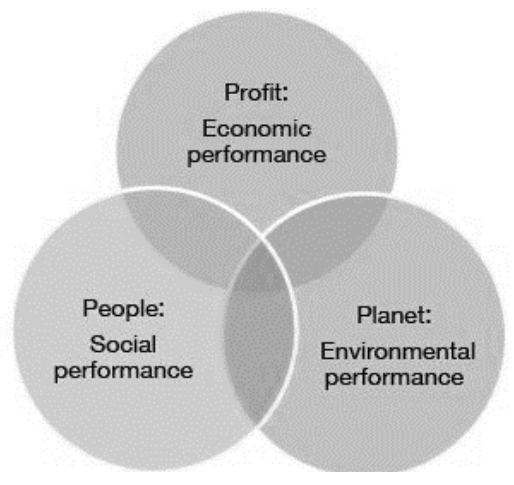

Fig. 2. The SRB model, 3 Ps or $\mathrm{TBL}^{3}$

For the purpose of minimizing this ambiguity, it has been proposed that the use of terms should be correct. If anyone decides to analyze the tridimensional construct, the right term to use will be sustainability and the term of social corporate responsibility (CSR) in case of focus is on the social areas. Sustainability and its related terms have used in different articles as literature.

\footnotetext{
${ }^{3}$ Source: Socially Responsible Business: A Model for a Sustainable Future by Isabel B. Franco through United Nation Publication in 2017.
} 
Some articles explain sustainability with issues of corporate environment and some articles explain this term with reference to social corporate issues which is related to social sustainability area of the company. Moreover, there are some articles which use the TBL term and classify sustainability with social and environmental issues and also relate with economic sustainability. The research work done by Freundlieb et al. [18] shows that sustainability and CSR are two concepts but they are more consistent just because of their strong relation and impacts in the firms and this consistency has based on normative constructs. The starting point for any consideration of CSR or sustainability lies in the predominant concepts of CSR and sustainability.

\subsubsection{Development in Sustainability}

In the perspective of history, the main focus was on sustainability development. From 1970s to 1980s, most of the studies were about social reporting but later on in 1990s, the main attention was on environmental reporting. In 2000s, trends were started to shift towards CSR analysis or sustainability reporting. These trends then directly involved to develop the standards by the Global Reporting Initiatives (GRI) [16]. As mentioned in the article of Aras \& Crowther [2] different stages show maturity for adoption of corporate sustainability and corporate social responsibility. First of all, companies start to involve for window dressing in activities by bringing change in the wording to show corporate social responsibility language by not taking into consideration about any substance. Secondly, they take some initiative for cost minimization by restructuring their business model and process to decrease the consumption of energy and water which helps to company in reducing cost and improving financial position and performance. Third stage is stakeholder engagement, where companies start to pay more attention on customer and employee satisfaction, which is very significant matter for any firm. The next stage contains the communication of all initiatives with developing corporate social responsibility reports. The last stage is about the sustainability, which bring changes at large scale in the practice of business and restructuring in business process. According to this framework, it seems the corporate sustainability concept has positive prospect as it focuses, captures and addresses all major issues of the public in regard of society and business relationships.

United nation has an agenda of 2030 for sustainable development for people, planet and prosperity. The main goal of this agenda is to eradicate poverty from targeted countries and strengthen global peace because these are the huge challenges for sustainable development. There are 17 sustainable 
development goals (SDG) and 169 targets need to achieve for bringing changes and to save this planet from critical issues by the end of 2030 . The following 5Ps which are included in agenda 2030 of United Nations are mentioned below Figure 3.

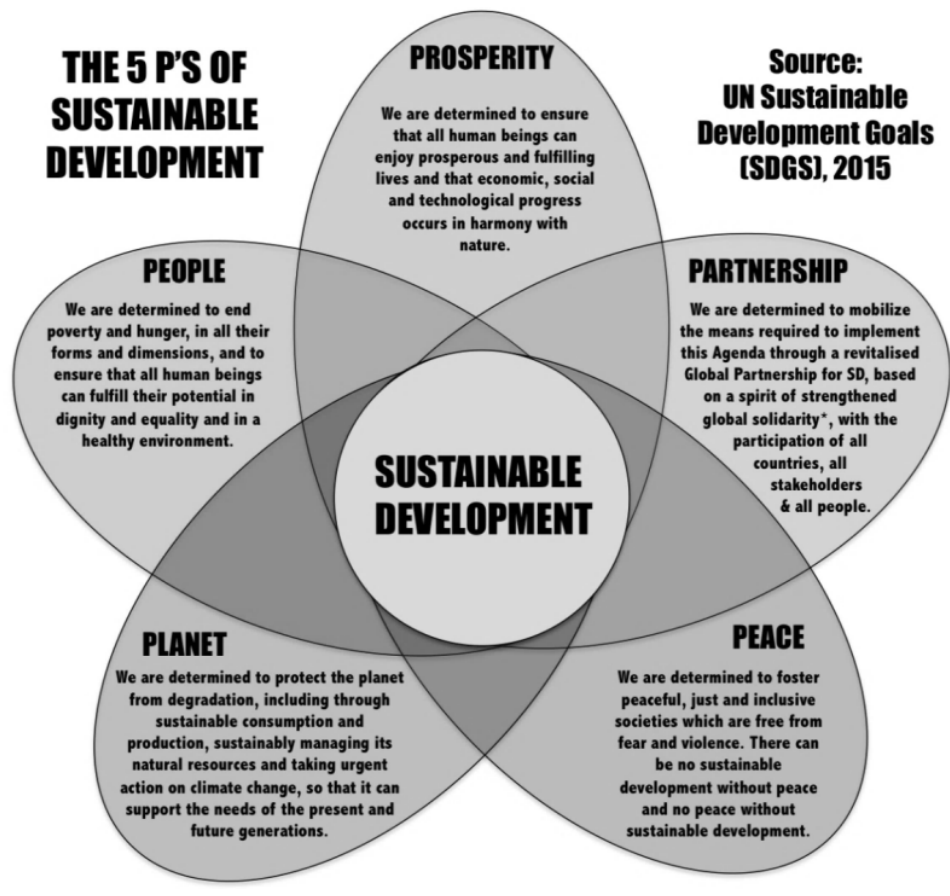

Fig. 3. 2030 Agenda of Sustainable Development by United Nations ${ }^{4}$

\footnotetext{
${ }^{4}$ Source: UN Sustainable Development Goals - Finalized Text \& Diagrams: http://www.waynevisser.com/wp-content/uploads/2015/08/sdgs-diagram.png
} 


\subsection{Corporate Social Responsibility}

As previous studies also stated that CSR helps to firms to build their goodwill which can be helpful to a company to get rid out of crisis. Positive and good reputation has a strong link with the financial outcomes and value of a company that help them to take a distinctive position in the competition with their competitors [6]. Similarly McWilliams and Siegel [23] mentioned about positive CSR:

"Creates a reputation that a firm is reliable and honest"

Roberts and Dowling [28] pointed out that optimistic approach is,

"Precisely because the development of a good reputation takes considerable time and depends on a firm making stable and consistent investments over time"

So, researchers have found that reputation is a very important asset of any company without any doubt and worth protective. Corporate social responsibility has a very detailed and long practice in so many countries. In recent years, its growth can be seen in response to limitations or failure of government regulations in regards to globalization, privatization and bringing the change in reforms of the welfare country. Moreover, a high positive change and likings of citizens in a state especially in many Western communities and also development in technology that have helped to people to bring ease in their life because of huge spread out of information can show its popularity [26].

Media and civil society highly requesting to companies to have look on the social and environmental issues in core activities and need to deliver transparency and ingenuousness with regards to their activities [17].

CSR not only includes but also move beyond to the legal and economic considerations, also involve voluntary acts. Therefore, if we conceptualize CSR is something that firm should consider it over and above their legal and economic criteria. Here is another question arises that what CSR means which involves a list of areas for the business have a big responsibility. So the answer of this question is that a firm should make decisions and utilize resources in different kinds of areas like: poverty, volunteer and social work, pollution problems, racial and discriminative problems and all other social problems where they see possibility to solve them [10]. 


\subsubsection{CSR in Supply Chain Management}

Normally researches done on CSR and SCM are parted in the theoretical work. Corporate social responsibility is widely relates to social problems and supply chains mostly related to environmental problems [9]. To observe the role of CSR in supply chain management is somehow critical in the real form because different professionals around the world are able to cope the lifecycle of different products. Supply chain is often more dispersed and uneven [19].

A very important feature of CSR is that which is more connected with the guarantee of the supplies and it is what, which indicates the extension of the practices of the corporate social responsibility in whole supply chain management. Companies with more socially responsibility, always ask to suppliers for being more socially responsible just for the sake of implementing CSR throughout the supply chain management. These kinds of organizations focus on the welfare of society, their efficiency in all aspects and the performance of their suppliers those who take in part into their activities. This is a way which helps to transfer socially responsible attitude in carrying along with the supply chain management. It will help to influence the actions of other groups having same interest. Moreover, it will help to deliver a basic standard of environmental and social principles need to be satisfied [21].

As the concept of supply chain management is developing but it has a very critical relationship with some other processes in all over the globe. Companies normally outsource their business into developing countries to get the advantage of low labor cost. When a company adopts sustainable supply chain principles then they present themselves accountable for the environmental and social impacts on the society and are forced to consider social and ecological aspects in their decision making and implement them along with their supply chains. When supply chain relationships involve into developing countries by outsourcing from companies then firms are supposed to play a significant role for the performance and well-being of the people work in those developing countries [31]. Even though with the very long history and development of corporate social responsibility, implementation of CSR and also sustainability concepts to supply chains (sustainable supply chain and green supply chain) have developed in recent few years. Sustainable supply chain management is well-defined for the management of supply chains where the sustainability of all three dimensions like economic, social, environmental are taken into consideration [13]. 


\subsection{Green Supply Chain Management}

Green supply chain management during the last five decades has developed from relationship of customer and supplier with information sharing on strategic basis in between supply chain management companies, but in recent years, GSCM specifically is paying attention on environment problems but not only for individual firm but as whole industry involves in supply chain management. It discusses about all the practices which includes activities starting from the generating an idea consisting design of green product, procurement of raw material, manufacturing goods then logistics but also to manage the wastage and reuse it [22]. GSCM can be categorized into practices of collaboration and monitoring to obtain economic and environmental goals [12]. To reach towards defined goals, all efforts of each department working with the firm along with all downstream, upstream supply chain associates are very necessary. In this current study, I followed the practices developed by Zhu et al. [33] for green supply chain management in internal and external both operations and these are very commonly used practices. Internal practices consist those which can be designed, planned then implemented in the company while external practices are depending on an organization external parties like customers, suppliers. Internal environmental management and EcoDesign is for internal practices and Green purchasing and Cooperation with customers and Investment Recovery are considered of being external practices [29].

\section{- Internal Environmental Management (IEM):}

Practice of IEM in GSCM of a company in as its strategy and show a strong commitment with vision of superiors, involvement of staff at middle level and spread out to the whole management across the organization with establishing a cross functional team. Organizations which are very proactive always pay attention on the internal environmental management (IEM) as a strong base for the whole green supply chain management procedure.

\section{- Eco-Design (ECO):}

Eco-design considers as a proactive methodology for controlling environmental issues also to make ensure that a firm follows all compliance for the prevention of pollution in the product lifecycle at early stage. ECO is also help to decrease the future cost to control the damages to environment. This concept take an organization to the level in reducing their manufacturing cost where they design a product by consuming less energy, utilization of few raw material, less toxic emissions which has 
positive impact on economic and environmental performance of a company.

- Green purchasing (GP):

GP is mainly pay attention on cooperation with suppliers and ask them to produce environment-friendly and sustainable products. Green purchasing is also known as planned purchasing for long run under the strategic plans by taking into consideration the awareness of environment requirements like possibility of recycling the products and waste minimization because the reusing products always help to a company to minimize their manufacturing cost and to make their performance more better.

- Cooperation with customers (CC):

In this green era, companies have to go beyond the traditional thinking by broad their thinking powers and show to their customers as they are strategic partners for collaboration to eradicate the environment problems. Cooperation with customers in a step where you involve your customer from step of eco-design till distribution then recover packaging but also take back the expired products bring into your practice. This is step which requires a long term relation should be established with your customers to bring more efficiency in whole process.

- Investment Recovery (IR):

This is step of green practice which includes all those benefits gained from the previous investments which were considered as waste in shape of waste materials. Investment recovery focuses on the sale of inventories which are excessive, reuse of material for gaining more benefits with the investments which company has spent on resources.

\subsubsection{Green Supply Chain Management Conceptual Development}

Supply chain management is a chain of process which starts from the supply to the demand of market for products and to payment by customers. A traditional supply chain management process is a network that attains raw material, make semi-finished products then final goods and deliver the final goods to end users with using a comprehensive logistic channel. Supply chain management covers whole information from the suppliers of supplier to the customers of customer. Figure 4. explains the structure of traditional supply chain management where focused is on the purchasing of raw material from supplier, its manufacturing and delivery of the finished product to final user [7]. 


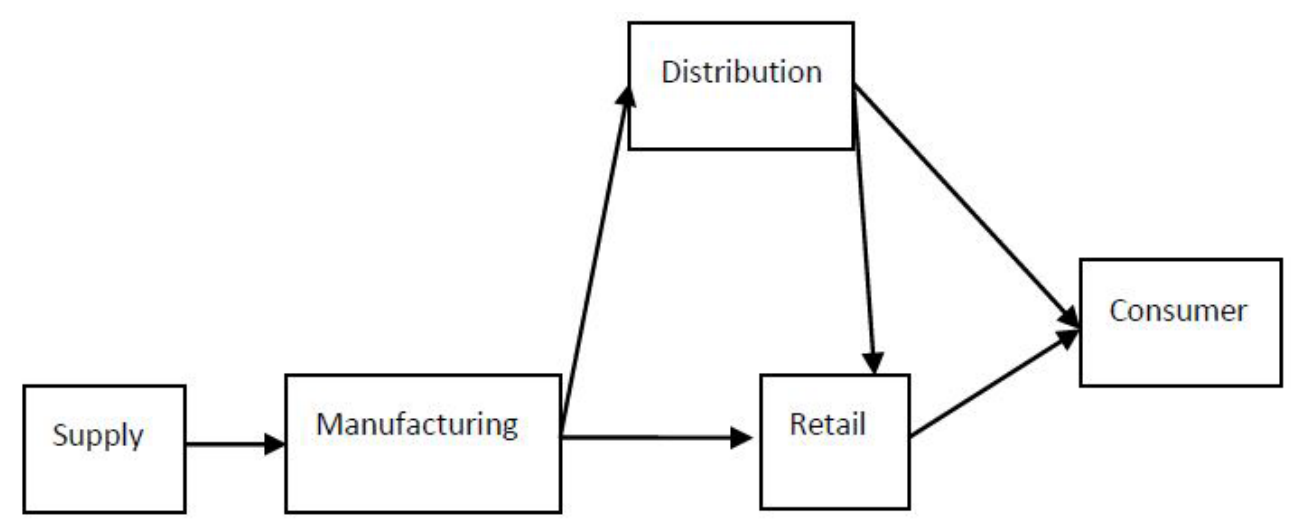

Fig. 4. the Traditional Supply Chain Management ${ }^{5}$

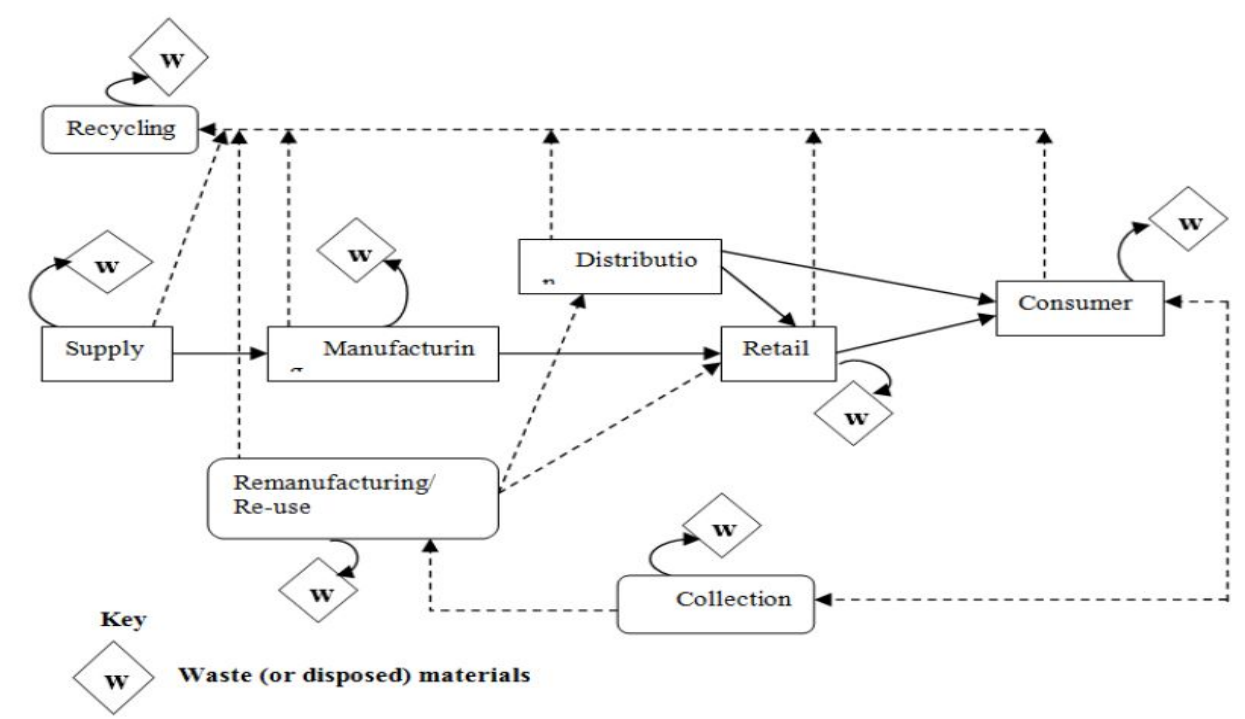

Fig. 5. the Green Supply Chain Management ${ }^{6}$

According to Bowen et al. [8] companies would follow the practice of green supply chain management after recognizing that GSCM can bring more benefits operationally, financially and environmentally. Companies who follow this practice they always know that GSCM, as seen in Figure 5., helps to bring more efficiency and collaboration in between the business partners

${ }^{5}$ Source: Beamon, B.M., "Designing the green supply chain," Logistics Information Management, vol. 12, pp. 332-342, 1999.

${ }^{6}$ Source: Beamon, B.M., "Designing the green supply chain," Logistics Information Management, vol. 12, pp. 332-342, 1999. 
and all other stakeholders. Therefore, it has been proved that GSCM increase financial and environmental performance of a company but also helps in minimize wastage by reusing it and save production cost.

\section{Methodology}

This paper is as a review paper discusses the theoretical background and development work in sustainability and CSR in green supply chain management through the most relevant literature to the current paper work. For the purpose of bringing some industrial taste from Pakistan into this paper and see how a particular firm is adopting the concepts to protect the environment and how they are contributing to society in term of their social responsibility. This paper takes a manufacturing company named as Lucky Cement Co. Limited, as its case study, from Pakistan that has adopted the sustainability and CSR practices in its core business and brings more innovations into its business along with green supply chain management.

\subsection{Overview of the Cement Company}

In Pakistan, Lucky Cement has involved into a premium cement manufacturer delivering consistent quality, providing unmatched customer satisfaction, utilizing state-of-the-art vertical and horizontal grinding technology, and most importantly, benefiting from low production costs.

\section{Vision}

According to the annual financial report 2018, the company has very comprehensive vision which says,

"Ensure sustainable leadership position in Pakistan \& increase global footprint in the cement sector. Identify \& capitalize on diversification opportunities to maximize shareholders' value while remaining socially responsive in all spheres of operations".

\section{Mission}

Company has a very comprehensive mission as compare to other companies in the same industry which contains sustainability and CSR with their green supply chain operations as stated in annual financial report 2018: 
"Company strives to be a growth oriented company by identifying opportunities, making the right investments, producing high quality cement and using innovative technology to achieve cost competitiveness and customer satisfaction. Company endeavors to harness the best human resources and providing them a level playing field in achieving long term goals. Company aims to deliver sustained growth and enduring value to its stakeholders. Company also recognizes its obligations towards environment and corporate social responsibility and seeks to mitigate any adverse effects on our environment".

\subsection{Compliance with GRI, Sustainability and CSR}

As stated in sustainability reports 2011 \& 2012, Company being the first ever company in Pakistan has got "A+" rating from Global Reporting Initiative (GRI) Netherland due to completely compliance with the sustainability requirements and present its sustainability performance in shape of sustainability report. Company has won the award of Company has won the second position as Best Corporate Report Awards in 2016 and in 2017, due to recognitions of its efforts towards sustainable development and contribution for protecting the overall environment for a greener Pakistan, Lucky cement got the Environment Excellence Award from National Forum for Environment and Health (NFEH). Meanwhile, this company also received an award of Best Corporate Social Responsibility due to its innovative efforts for fulfilling its corporate social responsibilities ${ }^{7}$.

As per company mission especially for the sustainability and CSR mention in their sustainability report 2018 :

\section{"From Strength to Strength"}

"Our progress lies in the development of our people. We strongly believe that investing in our human capital goes hand in hand with the growth of the Company. An environment conducive to growth, opportunities for self-actualization and a learning centric approach set our organization apart".

\footnotetext{
${ }^{7}$ Source: https://www.lucky-cement.com/investor-relations/downloads/financial-reports/
} 


\subsection{Sustainability Initiatives}

For the sustainability, company takes into consideration all areas of sustainability consisting, effective internal controls, ethical behavior, efficient operational procedures and energy conservation are an integral part of their business model.

\subsubsection{Environment}

Because the implementation of sustainability into its core business operations has always been one of the major aims of Lucky Cement. The company has been successful in establishing a leadership position in the market by achieving this target in its strategic orientations.

\subsubsection{Waste Heat Recovery Plant - acquisition of green technology}

In any Industrial process heat is wasted as a result. If not used efficiently, waste heat is released into the atmosphere. The company uses five Waste heat recovery (WHR) plants in two different factories to produce electricity that utilizes residual heat, consuming no fuel, and lowering dust emissions and temperature of discharged flue gas which has positive impacts on the environment. Company has significantly decreased its main expense with co-generating electricity from the wasted heat. The WHR units do not need to use fuel to operate because it uses the wasted heat from the system as fuel. Being one of the leading cement manufacturers in Pakistan, Lucky Cement has the responsibility and opportunity to contribute in bringing sustainability in the cement industry.

\subsubsection{Reduction in CO2 Emissions - further sustainability initiatives}

Lucky cement is equipped with high efficient bag houses to control various pollutants that are generated in cement manufacturing process. This company is an innovator for taking these steps of corporate social responsibility with application of dual fuel conversion project which helps to generate an environment friendly energy from furnace oil. The firm is also proactive for taking part in other practices for finding alternatives of fuel projects to achieve sustainability. This highlights Lucky Cement's vital position in preserving the ecosystem. 


\subsection{CSR initiatives}

This cement company takes pride in its employees and wants to develop a corporate culture that promotes social responsibility and welfare. Employees, of this company, are a key component of its CSR initiatives and their participation enhances what the company contributes to its communities.

\subsubsection{Education}

Company sees itself being committed for the welfare of society where it operates. Therefore, it has continued its services in the education sector by offering merit-based scholarships to deserving students in leading universities of the country. The company remains faithful to the cause of women empowerment in the country and continues to support two leading Government schools for girls in the biggest city of Pakistan in partnership with a welfare trust. Company is also focusing on social aspects for the betterment of women education in the country. Company hopes that its support for these institutes can change them as model institutions for the education of the girls of Pakistan. On the other hand, support for the maintenance of The Hub School also continues as well.

\subsubsection{Health and Aziz Tabba Foundation}

Company ensures its obligations for taking part in projects of health care in the country and provides financial support to Aziz Tabba Foundation known as the most famous philanthropic institute in Pakistan. Company supports for running of two more health care institutes. Furthermore, company extends its support for the treatment of blind children through Pakistan Welfare Association of the Blind.

\subsubsection{Volunteerism}

Company also engages its employee to take part in volunteer activities like Children of SOS Village and also provide support to athletics in Special Olympic Pakistan in organizing activities. Company also celebrates Employee Volunteer Day by considering an objective to bring awareness for social responsibility among the employees. Company also assist to some Government Girls High School in renovating and provide cement material free of cost as well as engage its employees to take part in decoration of the school.

Last but not the least, company also highlights the true spirit of charity in the holy month of Ramadan every year by supporting basic food needs to deserving families and donate for the cause of community development also. 
In order to fulfill their social responsibilities, company is giving a big amount for donations in different sectors including health initiatives and financial support for poor patients, community welfare, sports activities, education initiatives and financial support to schools and training institutions and other general donations. To show company's CSR in terms of figures from FY 2018, there are two charts below which shows an amount of donations in PKR:

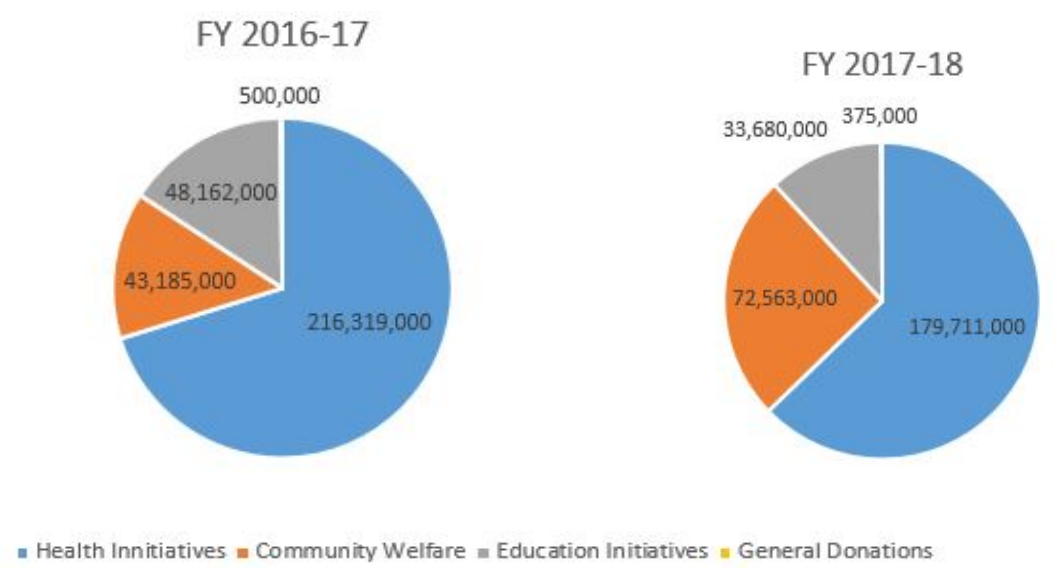

Fig. 6. Breakdown of the donations ${ }^{8}$

\section{Conclusion}

After thoroughly studied about sustainability and CSR in GSCM, this paper comes to stage that in 1970s and 1980s some firms remained followed one term in one time either it is sustainability or CSR in their supply chains but very few firms are adopting these two concepts (sustainability and CSR) in one time. In late 2000s, firms have started to follow sustainability and CSR at global level, and Lucky Cement Company in Pakistan considered as one of the leading firms, is following both concepts (sustainability and CSR). It won the sustainability reporting award in 2011, as the first ever company in Pakistan due to complete compliance with standard requirements specified by Global Revenue Initiative (GRI) Netherlands. Lucky Cements has great sense of corporate social responsibility and fully committed to play a major role in areas of education, health, women empowerment and they have taken green initiatives such as waste heat recovery plant and reduction of $\mathrm{CO} 2$ to protect the environment by making it more sustainable. The company is still not up-

\footnotetext{
${ }^{8}$ Source: Annual Report 2018: https://www.lucky-cement.com/investorrelations/downloads/financial-reports/
} 
to-mark as 5Ps mentioned in 2030 agenda of UN. This company needs to focus on other problems which are existing now by following guidelines prescribed by UN. This paper is review of sustainability and CSR terms in the perspective of a manufacturing firm who follow green supply chain management taking Lucky Cements from Pakistan as a case study. For future directions, a quantitative analysis is needed by taking data of different firms from different countries working in the same or different sectors in order to get a deep knowledge and clear picture of the said issue. 


\section{References}

[1] Quarshie AM, Salmi A, Leuschner R. Sustainability and corporate social responsibility in supply chains: The state of research in supply chain management and business ethics journals. Journal of Purchasing and Supply Management. 2016 Jun 1;22(2):82-97.

[2] Aras G, Crowther D. Governance and sustainability. Management Decision. 2008 Apr 4.

[3] Ashby A, Leat M, Hudson-Smith M. Making connections: a review of supply chain management and sustainability literature. Supply Chain Management: An International Journal. 2012 Aug 3;17(5):497-516.

[4] Salam MA. Retracted article: Corporate social responsibility in purchasing and supply chain. Journal of Business ethics. 2009 Apr 1;85(2):355-70.

[5] Bansal P. Evolving sustainably: A longitudinal study of corporate sustainable development. Strategic management journal. 2005 Mar;26(3):197-218.

[6] Bhattacharya CB, Sen S. Doing better at doing good: When, why, and how consumers respond to corporate social initiatives. California management review. 2004 Oct;47(1):9-24.

[7] Beamon BM. Designing the green supply chain. Logistics information management. 1999 Aug 1.

[8] Bowen FE, Cousins PD, Lamming RC, Farukt AC. The role of supply management capabilities in green supply. Production and operations management. 2001 Jun;10(2):174-89.

[9] Carbone V, Moatti V, Vinzi VE. Mapping corporate responsibility and sustainable supply chains: an exploratory perspective. Business Strategy and the Environment. 2012 Nov;21(7):475-94.

[10] Carroll AB. A three-dimensional conceptual model of corporate performance. Academy of management review. 1979 Oct 1;4(4):497-505.

[11] Chabrak N. Promoting corporate social responsibility and sustainability: a model of integrity. Article Title \& Authors. 2015 Jan 1:786.

[12] Chu SH, Yang H, Lee M, Park S. The impact of institutional pressures on green supply chain management and firm performance: Top management roles and social capital. Sustainability. 2017 May;9(5):764.

[13] Ciliberti F, Pontrandolfo P, Scozzi B. Investigating corporate social responsibility in supply chains: a SME perspective. Journal of cleaner production. 2008 Oct 1;16(15):1579-88.

[14] Carter CR, Rogers DS. A framework of sustainable supply chain management: moving toward new theory. International journal of physical distribution \& logistics management. 2008 Jun 13.

[15] Dyllick T, Hockerts K. Beyond the business case for corporate sustainability. Business strategy and the environment. 2002 Mar;11(2):130-41.

[16] Fifka M. The development and state of research on social and environmental reporting in global comparison. Journal für Betriebswirtschaft. 2012 Apr 1;62(1):45-84.

[17] Freeman RE, Harrison JS, Wicks AC, Parmar BL, De Colle S. Stakeholder theory: The state of the art. Cambridge University Press; 2010 Apr 1.

[18] Freundlieb M, Gräuler M, Teuteberg F. A conceptual framework for the quality evaluation of sustainability reports. Management Research Review. 2014 Jan 14.

[19] Gulati R, Nohria N, Zaheer A. Strategic networks. Strategic management journal. 2000 Mar;21(3):203-15.

[20] Franco IB, Chatterji T, Derbyshire E, Tracey J. Actioning the Global Goals for Local Impact. Singapore: Springer Nature Singapore Pte Ltd; 2019.

[21] Valdez-Juárez LE, Gallardo-Vázquez D, Ramos-Escobar EA. CSR and the Supply Chain: Effects on the Results of SMEs. Sustainability. 2018 Jul;10(7):2356. 
[22] Mathivathanan D, Kannan D, Haq AN. Sustainable supply chain management practices in Indian automotive industry: A multi-stakeholder view. Resources, Conservation and Recycling. 2018 Jan 1;128:284-305.

[23] McWilliams A, Siegel D. Corporate social responsibility: A theory of the firm perspective. Academy of management review. 2001 Jan 1;26(1):117-27.

[24] Montiel I. Corporate social responsibility and corporate sustainability: Separate pasts, common futures. Organization \& Environment. 2008 Sep;21(3):245-69.

[25] Montiel I, Delgado-Ceballos J. Defining and measuring corporate sustainability: Are we there yet?. Organization \& Environment. 2014 Jun;27(2):113-39.

[26] Moon J, Vogel D. Corporate social responsibility, government, and civil society. InThe Oxford handbook of corporate social responsibility 2008.

[27] Reed DJ. Stalking the elusive business case for corporate sustainability. World Resources Institute; 2001.

[28] Roberts PW, Dowling GR. Corporate reputation and sustained superior financial performance. Strategic management journal. 2002 Dec;23(12):1077-93.

[29] Saeed A, Jun Y, Nubuor SA, Priyankara HP, Jayasuriya MP. Institutional pressures, green supply chain management practices on environmental and economic performance: A two theory view. Sustainability. 2018 May;10(5):1517.

[30] Solomon C, Mohamad MN, Jamaluddin R. Development in corporate sustainability: The green supply chain management perspective and challenges. Journal of Asian Scientific Research. 2014 Oct 1;4(10):590.

[31] Wolters T. Transforming international product chains into channels of sustainable production: The imperative of sustainable chain management. Greener Management International. 2003 Oct 1(43):6.

[32] Yu M, Zhao R. Sustainability and firm valuation: an international investigation. International journal of accounting and information management. 2015 Aug 3.

[33] Zhu Q, Sarkis J, Lai KH. Institutional-based antecedents and performance outcomes of internal and external green supply chain management practices. Journal of Purchasing and Supply Management. 2013 Jun 1;19(2):106-17.

[34] Zhu Q, Sarkis J. Relationships between operational practices and performance among early adopters of green supply chain management practices in Chinese manufacturing enterprises. Journal of operations management. 2004 Jun 1;22(3):265-89. 